\title{
REVIEW
}

\section{Mitochondria: a target for cancer therapy}

\author{
*,1 Jeffrey S. Armstrong
}

${ }^{1}$ Department of Biochemistry, Faculty of Medicine, Yong Loo Lin School of Medicine, National University of Singapore, 8 Medical Drive, Singapore 117597, Singapore

Mitochondria, the cells powerhouses, are essential for maintaining cell life, and they also play a major role in regulating cell death, which occurs upon permeabilization of their membranes. Once mitochondrial membrane permeabilization (MMP) occurs, cells die either by apoptosis or necrosis. Key factors regulating MMP include calcium, the cellular redox status (including levels of reactive oxygen species) and the mobilization and targeting to mitochondria of Bcl-2 family members. Contemporary approaches to targeting mitochondria in cancer therapy use strategies that either modulate the action of Bcl-2 family members at the mitochondrial outer membrane or use specific agents that target the mitochondrial inner membrane and the mitochondrial permeability transition (PT) pore. The aim of this review is to describe the major mechanisms regulating MMP and to discuss, with examples, mitochondrial targeting strategies for potential use in cancer therapy.

British Journal of Pharmacology (2006) 147, 239-248. doi:10.1038/sj.bjp.0706556; published online 5 December 2005

Keywords: Mitochondria; apoptosis; Bcl-2; Bax; BH3 domain; cancer; mitochondrial membrane permeabilization; mitochondrial permeability transition; reactive oxygen species; cyclosporine A; mitochondrial membrane potential

\begin{abstract}
Abbreviations: AIF, apoptosis inducing factor; ANT, adenine nucleotide translocator; Apaf-1, apoptosis protease activating factor 1; BgK, bongkrekic acid; BIR, baculoviral IAP repeat; CARD, caspase recruitment domain; CsA, cyclosporine A; CyD, cyclophilin-D; $\Delta \Psi_{\mathrm{m}}$, mitochondrial membrane potential; Endo $\mathrm{G}$, endonuclease G; ETC, electron transport chain; GSH, glutathione; HtrA2/Omi, high temperature requirement protein A2; IAPs, inhibitors of apoptosis proteins; MMP, mitochondrial membrane permeabilization; mtDNA, mitochondrial DNA; PARP, polyADP ribose polymerase; PT, mitochondrial permeability transition; PVT, protein vicinal thiols; ROS, reactive oxygen species; Smac/DIABLO, second mitochondria-derived activator of apoptosis/direct IAP binding protein with low pI; TRAIL, TNF-related apoptosis-inducing ligand; Vpr, viral protein R; VDAC, voltage dependent anion channel; XIAP, X-linked inhibitor of apoptosis protein; zVADfmk, $N$-benzyloxycarbonyl-Val-Ala-Asp(OMe)-fluoromethylketone
\end{abstract}

\section{Introduction}

Mitochondria are the cells main energy producers and are therefore essential for cellular life; however, recent research has shown that these organelles play a key role in cell death when their membranes become permeabilized (Green \& Reed, 1998; Kroemer, 2002; Breckenridge \& Xue, 2004; Green \& Kroemer, 2004). Two facts illustrate the key role of mitochondrial membrane permeabilization (MMP) in cell death. Firstly, MMP results in dissipation of the mitochondrial membrane potential $\left(\Delta \psi_{\mathrm{m}}\right)$, a parameter that is required for many key mitochondrial functions including ion transport, protein import, biogenesis and energy conservation (Gordon et al., 2000; Smaili et al., 2000; Scheffler, 2001; Kroemer, 2002). Secondly, the consequence of MMP is always cell death, even if the death-stimulus is removed before the cell dies (Kroemer, 2002). MMP includes either outer membrane permeabilization or inner membrane permeabilization (Green \& Reed, 1998; Kroemer, 2002). Outer membrane permeabilization is regulated by an evolutionary conserved group of proteins known as the Bcl-2 family, which either promote or inhibit apoptosis by modulating the integrity of the mitochondrial outer membrane (Green \& Kroemer, 2004). Inner membrane permeabilization is regulated by the redox status of mitochondrial protein vicinal

*Author for correspondence; E-mail: bchjsa@nus.edu.sg thiols (Fagian et al., 1990; Gadelha et al., 1997; Kowaltowski et al., 2001; Armstrong \& Jones, 2002) and the mitochondrial permeability transition (PT) pore (Haworth \& Hunter, 1979; Zoratti \& Szabo, 1995; Brustovetsky \& Klingenberg, 1996; Woodfield et al., 1998). In this review, I discuss the mechanisms regulating MMP and give examples of contemporary mitochondrial targeting strategies for cancer therapy.

\section{The release of apoptotic factors from the intermembrane space after permeabilization of the mitochondrial outer membrane}

Apoptosis is an active form of cell suicide controlled by a network of genes and is an essential process during development as well as playing a key role in the pathogenesis of diseases including cancer (Green \& Reed, 1998; Kroemer, 2002; Breckenridge \& Xue, 2004; Green \& Kroemer, 2004). Apoptosis is characterized by nuclear condensation and fragmentation of chromosomal DNA during which the DNA is cut in nuclear scaffold regions to form 50 to 300 kilobase fragments, which are then cleaved at internucleosomal spacer regions forming smaller pieces of DNA in a process known as DNA laddering. Apoptotic cell death occurs by either of two 
distinct pathways, which include either ligand-dependent activation of cell surface receptors (e.g. Fas ligand or TNF $\alpha$ ) or activation of the mitochondrial death pathway; however, significant crosstalk occurs between these two pathways which serves to amplify the overall apoptotic response (Bredesen, 2000; Wajant, 2002; Schultz \& Harrington, 2003). The barrier to apoptosis induction depends on an intact outer membrane, which sequesters a variety of apoptotic proteins in an inactive form in the mitochondrial inter-membrane space. When the integrity of this membrane is lost, these proteins are released into the cytosol and either activate enzymes of the cysteine protease family, known as caspases, or act in a caspaseindependent fashion to bring about cell death. Caspasedependent factors include cytochrome $c$, Smac (second mitocondria-derived activator of caspases), also known as DIABLO (direct inhibitors of apoptosis protein (IAP) binding protein with low $\mathrm{pI}$ ) and possibly $\mathrm{HtrA} 2 / \mathrm{Omi}$ (high-temperature requirement protein A2), while caspase independent factors include apoptosis-inducing factor (AIF) and endonuclease G (Endo G) (van Loo et al., 2002; Kuwana \& Newmeyer, 2003). Recently, the role of a number of these proteins in apoptosis including $\mathrm{HtrA} 2 / \mathrm{Omi}$ and the caspase independent factors AIF and Endo $G$ has been questioned with the suggestion that these factors do not play an active role in induction of apoptosis (Ekert \& Vaux, 2005). Cytochrome $c$ is a small heme-containing protein adsorbed to the outer face of the inner membrane and involved in electron transport. It induces the energy-dependent (ATP/dATP) formation of an oligomeric complex known as the apoptotic protease-activating factor 1 (Apaf-1) apoptosome (Cain et al., 2002). The apoptosome possesses a caspase recruitment domain (CARD) that binds and processes caspase 9 to form a holoenzyme complex, which activates the so-called 'executioner' capase 3 (Cain et al., 2002). The cell is then dismantled through targeted proteolysis of a number of cellular substrates. This system is negatively regulated to prevent the inadvertent activation of apoptosis by the inhibitors of apoptosis proteins (IAPs). These proteins possess baculoviral IAP repeat (BIR) domains, which allows them to directly bind to specific caspases and inhibit their activity (Shi, 2002). The IAPs themselves are also regulated by the so-called IAP-inhibitor proteins including Smac/DIABLO and HtrA2/Omi, which have an IAP-binding motif that specifically interacts with the BIR domains of IAPs blocking IAP/caspase complex formation and thereby restoring caspase activity ( $\mathrm{Wu}$ et al., 2000; Shi, 2002). Smac/ DIABLO has an N-terminal 4 amino-acid IAP-binding motif that physically interacts with the surface groove of BIR3 domain of X-linked inhibitor of apoptosis protein (XIAP) (Chai et al., 2000). Since XIAP, which inhibits caspase-9 via interaction with its BIR3 domain, is inhibited by SMAC/ Diablo by specific binding to its BIR3, SMAC/Diablo restores caspase 9 activity. HtrA2/Omi is a mitochondrial serine specific protease that has been shown to cleave and inactivate cellular inhibitor of apoptosis protein (cIAP-1). Consequently, it has been reported to be involved in caspase-dependent as well as caspase-independent cell death by IAP neutralization (Suzuki et al., 2001; Jin et al., 2003). However, recent reports have cast doubt on the role of HtrA2/Omi in apoptosis since the protein has been shown to have a neuroprotective role and that it may be involved in the maintenance of mitochondrial function (Jones et al., 2003; Martins et al., 2004). AIF was identified as a mitochondrial protein causing chromatin condensation and high molecular weight DNA fragmentation without DNA laddering (Susin et al., 1999). It is a flavoprotein oxidoreductase possessing three distinct domains including an FAD-binding domain, an NADH-binding domain, and a Cterminal domain (Susin et al., 1999; Mate et al., 2002). The FAD binding domain is required for its oxidoreductase activity, but neither FAD nor oxidoreductase activity are necessary for the proposed proapoptotic function of AIF indicating that AIF may be a bifunctional protein involved in mitochondrial electron transfer as well as apoptosis (Miramar et al., 2001). The role of AIF in apoptosis has recently been challenged since it was shown that AIF was involved in respiratory complex I formation. This suggested that its true function may be related to oxidative phosphorylation (Vahsen et al., 2004). Endo $G$ is a mitochondrial protein residing in the intermembrane space that mediates internucleosomal DNA fragmentation in association with other proteins like AIF (Widlak \& Garrard, 2005). Although, genetic disruption of the Endo $G$ gene in mice abolished the nuclease activity of the Endo G protein, it had no effects on nuclear DNA degradation in apoptosis assays. Also, since these mice were viable and showed no age-related abnormalities suggested that Endo G may have a function unrelated to apoptosis (Irvine et al., 2005). Indeed, both AIF and Endo $G$ are released from mitochondria during apoptosis, but this appears to be a late event after commitment to apoptosis (Ekert \& Vaux, 2005). In summary, although many factors are released from mitochondria during apoptosis, it is not completely clear which of these factors are absolutely required for apoptosis induction. Although cytochrome $c$ and smac/DIABLO seem to be important for apoptosis, for other factors such as HtrA2/ Omi, AIF and Endo G the case is not so clear. Indeed, since it has been suggested that the AIF and Endo G pathways have more evolutionarily ancient origins their true function may be unrelated to apoptosis.

\section{Regulation of mitochondrial outer membrane permeabilization by the Bcl-2 family}

Proteins of the Bcl-2 family play a key role in apoptosis by their regulation of the integrity of the mitochondrial outer membrane. Proteins such as $\mathrm{Bcl}-2$ and $\mathrm{Bcl}-\mathrm{XL}$ prevent the release of apoptogenic proteins from mitochondria and therefore protect against outer membrane permeabilization while proapoptotic Bcl-2 family members, such as Bax and Bak, induce outer membrane permeabilization and cause the release of proapoptotic factors from mitochondria (Gottlieb, 2000; Daniel et al., 2003). Bcl-2 proteins contain regions of aminoacid sequence similarity known as Bcl-2 homology $(\mathrm{BH})$ domains. For example, Bcl-2 has four domains including $\mathrm{BH} 1-\mathrm{BH} 4$, although it is only the $\mathrm{BH} 4$ domain that is required for its antiapoptotic function (Daniel et al., 2003). Over the years a variety of mechanisms have been proposed to explain the antiapoptotic function of Bcl-2. For example, in a seminal paper by Hockenbery et al. (1993) in 1993 Bcl-2 was suggested to be a antioxidant or redox regulating protein. Conversely, Steinman in 1995 suggested that Bcl-2 was a prooxidant because its overexpression resulted in increased cellular antioxidant levels, that is, its antiapoptotic mechanism involved cellular adaptation to oxidative stress (Steinman, 1995). Bcl-2 has been suggested to be a channel forming 
protein because when it was incorporated into lipid membranes it blocked the ion conducting activity of the adenine nucleotide translocator (ANT) and the Bax protein (Brenner et al., 2000). Other proposed mechanisms have included the phosphorylation/dephosphorylation status of the protein (Ito et al., 1997), and the ability of Bcl-2 to heterodimerize with proapoptotic Bcl-2 family members and thereby block their targeting to mitochondria (Yin et al., 1994; Sedlak et al., 1995). To date, no theory has completely explained the mechanism of action of Bcl-2 in all situations, which may be, in part, due to the multiplicity of actions of the protein at the molecular level.

Bax and Bak are proapoptotic proteins that contain three $\mathrm{BH}$ domains $(\mathrm{BH} 1-\mathrm{BH} 3)$ and since cells lacking these two proteins do not undergo outer membrane permeabilization in response to apoptotic stimuli, they are considered to be key players in apoptosis induction (Degli Esposti \& Dive, 2003). Bax is either loosely attached to the outer membrane or sequestered in the cytosol through interactions with a number of protein factors including humanin, $\mathrm{Ku} 70$ and the 14-3-3 isoforms $\sigma, \theta, \varepsilon, \zeta$ (Guo et al., 2003; Nomura et al., 2003; Sawada et al., 2003). The active part of Bax is the C-terminal tail which, in the latent state, is sequestered by proline 68 into a hydrophobic pocket formed by its $\mathrm{BH} 1, \mathrm{BH} 2$ and $\mathrm{BH} 3$ domain (Nechushtan et al., 1999; Schinzel et al., 2004). Bak, on the other hand, has a tail anchor that attaches it to the mitochondrial outer membrane in a complex with the voltage-dependent anion channel (VDAC2) (Cheng et al., 2003). When the cell receives an apoptotic stimulus, the conformations of Bak and Bax change, resulting in their oligomerization and the formation of a pore in the outer membrane through which apoptotic factors are released from the mitochondrial intermembrane space (Korsmeyer et al., 2000). It is also thought that key lipids are involved in pearmabilization of the outer membrane since cardiolipin, a mitochondrial lipid known to be concentrated in the inner membrane, is also present at contact sites between the outer and inner mitochondrial membranes (Ardail et al., 1990; Petrosillo et al., 2003). Other proapoptotic Bcl-2 proteins contain only the $\mathrm{BH} 3$ domain and are involved in the activation of Bax and Bak proteins. These proteins fall into two classes including Bid and Bim proteins, which induce oligomerization and targeting of Bax and Bak to mitochondria (Eskes et al., 2000), and Bad and Bik proteins that bind Bcl-2 and displace sequestered Bid-like proteins resulting in outer membrane permeabilization (Chen et al., 2005). In summary, the $\mathrm{Bcl}-2$ proteins act either alone or in a concerted manner with other proteins to regulate the permeability of the outer membrane by mechanisms that appear to include the ability of these proteins to form ion channels or pores in membranes as well as possible physical interactions with other Bcl-2 family members and other proteins implicated in apoptosis regulation.

\section{Therapeutic strategies for targeting the Bcl-2 family and the mitochondrial outer membrane}

Bcl-2 is overexpressed in many solid organ tumors and plays a key role regulating the response to conventional cancer treatment because it increases resistance to cell death. For this reason a number of strategies aimed at decreasing Bcl-2 resistance to cell death are currently being developed (Miyashita \& Reed, 1992). One way to overcome the antiapoptotic action of $\mathrm{Bcl}-2$ has been found with thiol crosslinking agents such as diazenedicarboxylic acid bis $5 \mathrm{~N}$, $\mathrm{N}$-dimethylamide (diamide). In vitro assays showed that $\mathrm{Bcl}-2$ did not protect against diamide-triggered loss of $\Delta \psi_{\mathrm{m}}$ and the release of cytochrome $c$ (Zamzami et al., 1998). The same group of investigators later found that diamide acted by oxidizing a critical cysteine residue of ANT, which converted the protein into a nonspecific pore and induced the PT (Costantini et al., 2000a). These data indicated that thiol crosslinking agents might be potentially useful for therapeutic use against $\mathrm{Bcl}-2$ overexpressing tumors since they would target the mitochondrial inner membrane/PT pore causing protein oxidation and MMP independently of Bcl-2. However, since these agents would kill normal as well as cancer cells, one problem with this approach would be how to selectively target the cancer cells rather than normal tissue. Since membranepermeable cationic molecules including fluorescent dye Rhodamine 123 (Rh123) concentrate in mitochondria of cancer cells due to a higher $\Delta \psi_{\mathrm{m}}$ compared to normal cells (Chen, 1988), it may be possible to link these dyes to thiol modifying agents such as diamide, which would then theoretically target and kill the tumor cells. To date, this approach has not been tried, possibly because of the inherent toxicity of thiol crosslinking agents such as diamide. A second proposed strategy to overcome $\mathrm{Bcl}-2$-mediated resistance has been to use ligands of the mitochondrial benzodiazepine receptor (BR). The $\mathrm{BR}$ is a mitochondrial membrane protein that interacts with the VDAC and ANT (McEnery et al., 1992). PK11195 is a ligand of the BR and has been found to reverse the resistance to apoptosis in Bcl-2-overexpressing cells (Hirsch et al., 1998).

Other approaches to target $\mathrm{Bcl}-2$ have included the use of antisense technology to modulate protein expression. The principle behind antisense technology is the sequence-specific binding of an antisense oligonucleotide to target mRNA, resulting in the prevention of gene translation. The specificity of hybridization makes antisense treatment an attractive strategy to selectively modulate the expression of genes involved in the pathogenesis of diseases and has been used for Bcl-2. Antisense targeting of Bcl-2 by G3139 (Genasense oblimersen sodium), a phosphothioate oligonucleotide (18 modified DNA bases) caused apoptosis and increased the susceptibility of cells to treatment with low concentrations of staurosporine and ceramide (Marcucci et al., 2005). Both in vitro and in vivo studies have demonstrated antitumor activity of G3139 (Ackermann et al., 1999).

An alternative approach to the downregulation or inhibition of $\mathrm{Bcl}-2$ to induce apoptosis has been to target proapoptotic Bcl-2 peptides to mitochondria. For example, gene therapy employing Bax-delivering vectors has shown to be a successful strategy for activating mitochondrial apoptosis. Kagawa et al. (2000) used a binary adenoviral system under control of the GAL4 regulatory system to overexpress the proapoptotic molecule Bax, which when targeted to lung carcinoma cells shown extensive apoptosis. While Xiang et al. (2000), using an inducible recombinant Bax adenovirus, showed that overexpression of Bax sensitized ovarian cancer cells to apoptosis. Others have also found similar proapoptotic effects using adenoviral Bax-delivering vectors (Li et al., 2001). Aqeilan et al. (1999) used a recombinant chimeric protein containing interleukin 2 (IL-2) protein fused to Bax, which they showed selectively bound and killed cells bearing the IL-2 receptor 


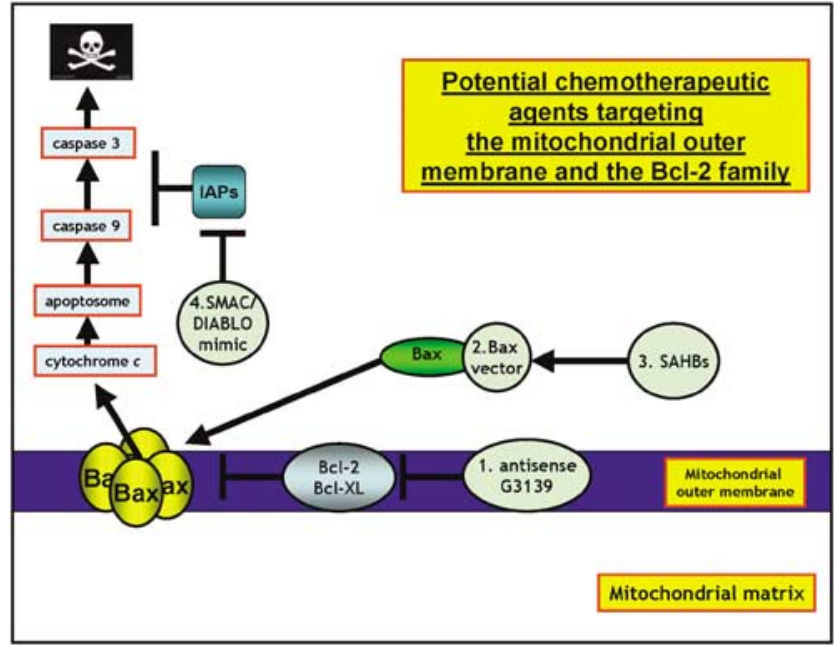

Figure 1 Potential chemotherapeutic approaches targeting the mitochondrial outer membrane and the Bcl-2 family: mitochondrial outer membrane permeabilization is regulated by the Bcl-2 family of proteins therefore targeting strategies to induce apoptosis are aimed at either inhibiting Bcl-2 antiapoptotic proteins or inducing Bax-like proapoptotic proteins. (1) Use of gene silencing technology, for example, Genasense G3139 to downregulate Bcl-2 expression. (2) Bax vectors have been used to deliver Bax and form a pore in the MOM that releases proapoptotic cytochrome $c$ and other factors from the intermembrane space. (3) BH3 stapled peptides (SAHBs) that activate Bax have been employed to induce apoptosis. (4) The caspases are negatively regulated by a family of proteins known as the IAPs including XIAP; however, these themselves are also regulated by the IAP-inhibitor proteins such as Smac/DIABLO, which serves to restore caspase activity. Smac/DIABLO mimics have recently been used to induce apoptosis (see text for references).

in vitro. Another approach to induce apoptosis was taken by Walensky and co-workers, who designed a BH3 peptidomimetic, which mimicked the BH3 helix of Bid. The peptidomimetic was generated using a chemical strategy known as hydrocarbon stapling, which produced $\mathrm{BH} 3$ stapled peptides, which they called stabilized $\alpha$-helix of BCL-2 domains (SAHBs). The peptidomimetic was shown to be proteaseresistant and cell-permeable and possessed increased binding affinity to multidomain Bcl-2 proteins. A SAHB of the BH3 domain from the Bid protein induced apoptosis in leukemia cells and inhibited the growth of human leukemia xenografts in vivo (Walensky et al., 2004). An alternative idea has been to develop mimics of other apoptosis inducing proteins including the protein Smac/DIABLO. For example, Li and co-workers synthesized a small molecule mimic of Smac/DIABLO containing the four amino-terminal residues that interact with the BIR domain of IAPs. The compound bound to XIAP and cIAP-1 and synergized with both tumor necrosis factor (TNF) and TNF-related apoptosis-inducing ligand (TRAIL) to activate caspases and induce apoptosis in human cancer cells (Li et al., 2004). The strategies described above for targeting $\mathrm{Bcl}-2$ protein to the mitochondrial outer membrane is shown schematically in Figure 1.

\section{The PT and its role in cell death}

The PT refers to an abrupt transition in mitochondrial permeability that occurs when mitochondria in vitro are treated with calcium and reagents that increase oxidative stress (Haworth \& Hunter, 1979; Zoratti \& Szabo, 1995; Brustovetsky \& Klingenberg, 1996; Woodfield et al., 1998; Crompton, 1999). The phenomenon was first characterized by Hunter and Haworth in the late 1970s and was suggested to be the result of opening of discrete sized pore $(\sim 1500 \mathrm{Da})$ in the mitochondrial inner membrane (Haworth \& Hunter, 1979). The basic structure of the PT pore was suggested to include the VDAC, ANT and cyclophilin-D (CyD), a member of a family of highly homologous peptidylprolyl cis-trans isomerases (Haworth \& Hunter, 1979; Zoratti \& Szabo, 1995; Brustovetsky \& Klingenberg, 1996; Green \& Reed, 1998; Woodfield et al., 1998; Crompton, 1999; Scheffler, 2001). These proteins were proposed to interact at specialized contact sites between the mitochondrial outer and inner membranes and form the basic PT pore structure along with possibly other constituent proteins including the BR and creatine and adenylate kinases (Fagian et al., 1990; Zoratti \& Szabo, 1995; Crompton et al., 1998; Green \& Reed, 1998; Crompton, 1999; 2000; Breckenridge \& Xue, 2004). The in vitro activation of the PT was observed to be potently inhibited by the immunosuppressant drug cyclosporine A (CsA), which led to its wide spread use in characterization of the PT (Crompton et al., 1998; Woodfield et al., 1998; Crompton, 1999; 2000). Since calcium and oxidative stress were potent activators of the PT in vitro, it was suggested that the PT might be mechanistically linked to the cell death observed during cardiac ischemia-reperfusion or glutamate-induced excitotoxicity in neurons since both forms of cell death are accompanied by increased calcium levels and oxidative stress (Schinder et al., 1996; Crompton, 1999; Halestrap et al., 2004). These ideas were further supported with the observation that CsA prevented both forms of cell death (Schinder et al., 1996; Halestrap et al., 2004). Gradually, the concept emerged that the PT might play an instrumental role in cell death during necrosis and apoptosis and consequently research focused on its regulation in an attempt to better understand diseases associated with deregulated cell death including cancer.

\section{The role of the $\mathrm{PT}$ in cytochrome $c$ release and apoptosis}

Early models describing the role of the PT in cell death suggested that the mechanism of release of apoptotic factors from the mitochondrial intermembrane space involved a number of discrete steps. These were thought to include (1) loss of $\Delta \psi_{\mathrm{m}}$, (2) increased colloid-osmotic swelling of the mitochondrial matrix and (3) mechanical disruption of the outer membrane and subsequent release of apoptotic factors into the cytosol (Marchetti et al., 1996; Susin et al., 1996; Vander Heiden et al., 1997; Lemasters et al., 1998; Green \& Reed, 1998; Kuwana \& Newmeyer, 2003). However, in contrast to this idea, Gao et al. (2001) found that mitochondrial swelling in HeLa cells did not result in cytochrome $c$ release, while Martinou and co-workers observed that the mitochondria from nerve growth factor (NGF) deprived neurons released cytochrome $c$ to the cytosol but were structurally intact and recovered their cytochrome $c$ content when NGF was added back. These reports indicated that the release of cytochrome $c$ from mitochondria can occur without complete disruption of the outer membrane (Martinou et al., 
1999). This view was also supported by von Ahsen et al. (2000), who showed that after treatment with $\mathrm{Ca}^{2+}$ isolated Xenopus mitochondria swelled dramatically but retained intact outer mitochondrial membranes. Thus, taken together, these reports indicated that mitochondrial swelling due to the PT was not sufficient for cytochrome $c$ release and other mechanisms must be involved.

\section{The use of CsA to characterize PT involvement in cell death}

The inhibition of cell death by CsA has been taken to indicate that the mechanism involved depends on the PT because CsA prevents CyD binding to the ANT and PT activation (Waring \& Beaver, 1996; Green \& Reed, 1998; Crompton, 1999). For example, Crompton and co-workers recently showed that when CyD was overexpressed, it induced the PT, presumably by binding and activating the ANT, and necrosis (Li et al., 2004). Recently, two independent groups reported in the journal Nature that the mitochondria of mice lacking CyD were resistant to the CsA-sensitive PT in vitro (Baines et al., 2005; Nakagawa et al., 2005). These reports confirmed a role for $\mathrm{CyD}$ in the $\mathrm{PT}$ in vitro and seemed to validate the use of CsA to characterize the involvement of the PT in cell death. However, in these reports the cell death induced by PT was necrotic and not apoptotic and was unregulated by the Bcl-2 proteins. Since CsA is a potent inhibitor of various forms of apoptosis indicates that it may be inappropriate to use this agent to characterize the PT during cell death (Green \& Reed 1998; Halestrap et al., 2002; Kim et al., 2003). Furthermore, CsA is not specific for CyD but binds to other proteins as well as the cyclophilin family proteins, which could be involved in its inhibitory effects on cell death (Fruman et al., 1992; Waldmeier et al., 2003). Also, CsA partitions in biological membranes, which could modify the characteristics of the lipid bilayer and alter membrane permeability as well as mediate direct affects on the PT (Epand et al., 2002).

\section{The PT and the protein thiol redox status}

In addition to calcium, the PT is also known to be regulated by the mitochondrial thiol-redox status which is, in part, maintained by levels of glutathione (GSH) (Griffith \& Meister, 1985; Martensson et al., 1990; Fernandez-Checa et al., 1998). Loss of GSH leads to mitochondrial protein oxidation, MMP and necrosis (Armstrong et al., 2002; 2004). Bernardi's group showed that oxidative stress triggered the PT in vitro and this involved oxidation of regulatory vicinal thiols in the ANT, suggesting a model where the PT was redox-regulated (Petronilli et al., 1994; Chernyak \& Bernardi, 1996; Costantini et al., 1996). Kowaltowski et al. (2001) went further to suggest that the PT was simply the result of oxidation of one or more mitochondrial proteins rather than opening of a preformed pore made up of native proteins. This redox-PT model is in harmony with a number of findings of Nakagawa et al. (2005) and Baines et al. (2005). First, the redox-PT is not blocked by CsA (which regulates Bcl-2-dependent cell death, i.e. apoptosis). Second, cell death after activation of the redox-PT is always necrosis and not apoptosis, and third the redox-PT is not regulated by Bcl-2 family proteins (Marzo et al., 1998; Zamzami et al., 1998; Costantini et al., 2000a; Armstrong \& Jones, 2002). Thus, the redox-PT is a mitochondrial inner membrane phenomenon. The two models of the PT may, in reality, reflect extremes of a continuum of actual changes that occur to the mitochondrial inner membrane before permeabilization occurs and involve a host of factors including calcium and oxidative stress. However, in terms of potential protein targeting for cancer therapy, it is clear that the inner membrane and the ANT play a key role in MMP. Therefore, targeting the mitochondrial inner membrane and the PT represents an attractive chemotherapeutic modality to eradicate cancer cells.

\section{Regulation of the PT by Bcl-2 family members: a potential link between inner and outer membrane permeabilization?}

In 1998, an article from Kroemers group published in the journal Science reported that the ectopic expression of Bax induced cell death in wild type, but not in ANT-deficient yeast, indicating that Bax targets the ANT to mediate cell death (Marzo et al., 1998), while another study showed that Bax interacted with VDAC to modulate apoptosis (Adachi et al., 2004). These studies indicated that Bcl-2 family members target one or more components of the PT to modulate cell death. Supporting this idea, Kroemers group also showed that mitochondria isolated from Bcl-2-transfected cells resisted activation of the PT, indicating that Bcl-2 family regulate both the PT and apoptosis (Susin et al., 1996). In contrast to these reports, a recent in vitro study showed that mitochondria isolated from Bax deficient HCT116 cell lines underwent similar calcium-mediated swelling profiles regardless of the level of Bax expression concluding that Bax does not regulate the PT (De Marchi et al., 2004). In agreement with this study, two reports in Nature showed that the PT regulates necrosis, it is not involved in apoptotic cell death and is not regulated by Bcl-2 family members (Baines et al., 2005; Nakagawa et al., 2005). In conclusion, it appears that two fundamentally different mechanisms are involved in the regulation of MMP and cell death, one which is predominantly an inner membrane phenomenon and involves protein thiol oxidation and activation of the PT and the other which is predominantly an outer membrane phenomenon and is regulated by the Bcl-2 family of proteins.

\section{Therapeutic strategies for targeting the mitochondrial inner membrane and the PT}

In addition to selective targeting of Bcl-2 family members to the mitochondrial outer membrane to initiate or enhance apoptosis, other strategies may be potentially useful in cancer therapy including: (1) the use of toxic agents that specifically target the mitochondrial inner membrane or its proteins including the PT; (2) the use of lipophilic cations that preferentially accumulate in the mitochondrial matrix of cancer cells compared to normal cells (Chen, 1988); (3) the use of toxic peptides such as mastoparan that target the $\Delta \psi_{\mathrm{m}}$ and (4) and agents that target and deplete mtDNA. Conven- 
tional anticancer agents such as doxorubicin, cisplatin, and paclitaxel cause MMP in an indirect manner by activating proapoptotic second messengers, for example p53, ceramide/ GD3 pathway and the Fas/FasL system (Costantini et al., 2000b). However, there are a number of agents that induce cell death independently by acting directly on mitochondrial membranes including arsenite, lonidamine (LND), betulinic acid, CD437 and viral protein $\mathrm{R}$ (Vpr) (Costantini et al., 2000b).

Arsenite targets mitochondrial membranes and causes cell death in leukemic cells. In one study, arsenite toxicity was modulated by L-buthionine sulphoximine (Zhu et al., 1999), suggesting that the mechanism involves modulation of mitochondrial protein thiol redox status (Costantini et al., 1996), and although arsenite did not cause oxidation of Cys56 of ANT, it was suggested that the drug induced PT since cell death was effectively blocked by CsA (Larochette et al., 1999; Costantini et al., 2000b).

Lonidamine (LND) is an antitumoral drug derived from indazole-3-carboxylic acid. LND targets mitochondria inhibiting oxygen consumption blocking energy metabolism (Stryker \& Gerweck, 1988). LND caused loss of $\Delta \psi_{\mathrm{m}}$ and the release of cytochrome $c$ from isolated mitochondria. Since these effects were blocked by CsA indicated that LND targeted the PT. In addition, LND induced permeabilization of liposomes into which the purified PT pore had been reconstituted. These results indicated that LND induced cell death via a direct effect on the PT (Ravagnan et al., 1999).

CD437 (6[3-adamantyl-4-hydroxyphenyl]-2-naphthalene carboxylic acid) is a synthetic retinoic acid receptor ( $\operatorname{RAR} \gamma)$ agonist that has been shown to induce cell death independently of its action on RAR $\gamma$ (Costantini et al., 2000b). CD437 has been found to induce mitochondrial release of cytochrome $c$, to activate caspases and to induce nuclear signs of apoptosis, all of which were blocked by CsA indicating that CD437 exerts its cytotoxic effects via activation of the PT (Marchetti et al., 1999).

Betulinic acid is a pentacyclic triterpene that has been found to induce apoptosis via a direct effect on mitochondria both in intact cells as well as in cell-free systems (Costantini et al., 2000b). Betulinic acid directly induced the loss of $\Delta \psi_{\mathrm{m}}$ in isolated mitochondria, which was not inhibited by the caspase inhibitor zVADfmk, indicating that it was activating the PT and inducing necrosis.

Mastoparan is a 14-amino acid $\alpha$ helical amphipathic peptide obtained from wasp venom. The $\alpha$-helix is a major structural motif of the peptide and is required for its function as it is with $\mathrm{BH} 3$ domains of proapoptotic peptides. However, whereas $\mathrm{BH} 3$ peptides specifically target the amino acids of the hydrophobic groove region of antiapoptotic molecules and inhibit their activity, the $\alpha$-helix of mastoparan penetrates membranes by a mechanism which is dependent upon the $\Delta \psi_{\mathrm{m}}$. Mastoparan has been suggested to facilitate opening of the PT through a bimodal mechanism. In the submicromolar concentration range, the action of mastoparan was observed to be dependent upon the calcium concentration and was inhibited by CsA; whereas, at concentrations above $1 \mu \mathrm{M}$, its action was independent of calcium and CsA (Pfeiffer et al., 1995). Therefore, although both $\mathrm{BH} 3$ and mastoparan peptides contain similar structural motifs, which are required for killer activity $\mathrm{BH} 3$ domains specifically target proteins involved in regulating mitochondrial outer membrane integrity; whereas, mastoparan targets the mitochondrial inner membrane and PT to mediate its effects.

The Vpr from human immunodeficiency virus- 1 also has an $\alpha$-helix with several cationic charges that concentrate on the same side of the helix (Schuler et al., 1999). Vpr induces cell death via a mitochondrial effect that is blocked by CsA and BgK (Jacotot et al., 2000). Surface plasmon resonance has shown that the $\mathrm{C}$-terminus of $\mathrm{Vpr}$ is responsible for apoptosis via a direct effect on the PT by binding to the ANT (Jacotot et al., 2000). Taken together, these reports suggest that peptides with a certain structural motif specifically target mitochondria and the PT and therefore may be useful in treating cancer.

An alternative mitochondrial targeting strategy that utilizes the mitochondrial protein-import machinery to deliver macromolecules to mitochondria has also been proposed. For example, a mitochondrial signal sequence has been used to direct green fluorescent protein to mitochondria to allow mitochondria to be visualized in living cells (Murphy, 1997). Alternatively, the protein-import machinery can be used to take up mitochondrial signal peptides. For example, fusion of the mitochondrial signal sequence to calcium-sensitive protein aequorin has produced a chimeric protein that targets to the mitochondrial matrix and has been successfully used to determine mitochondrial calcium levels within intact cells (Brini et al., 1995). Compounds localized to mitochondria this way offer potential as anticancer agents.

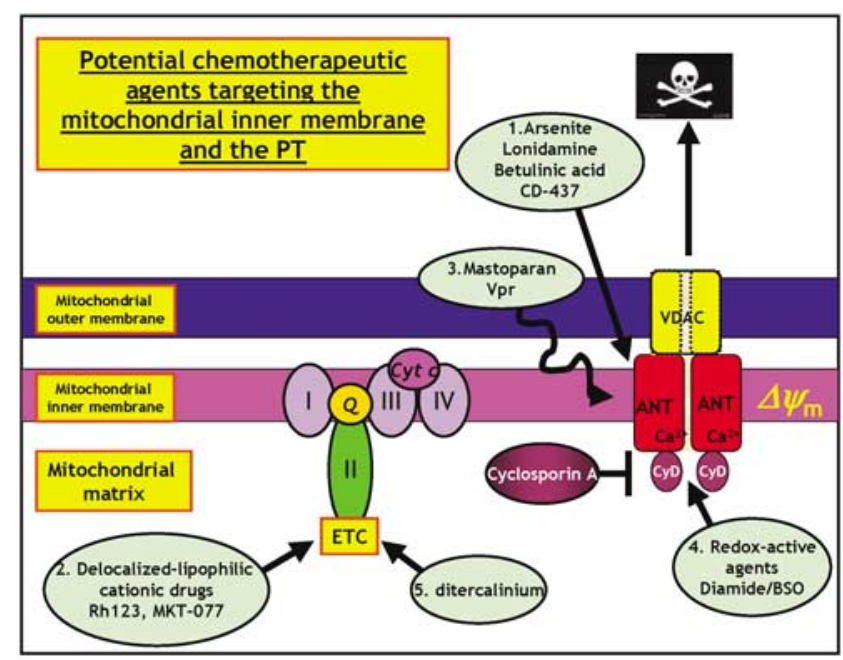

Figure 2 Potential chemotherapeutic approaches targeting the mitochondrial inner membrane and the mitochondrial permeability transition (PT). Mitochondrial inner membrane permeabilization and the PT is regulated by calcium and oxidative stress. Targeting strategies include activating the PT, inhibiting electron transport and oxidative phosphorylation and depleting mtDNA. (1) Agents such as arsenite, lonidamine, betulinic acid and CD437 target the PT and induce loss of $\Delta \psi_{\mathrm{m}}$. (2) Delocalized lipophilic cations accumulate in the mitochondria matrix due to the electrochemical gradient and cause loss of respiration and inhibition of electron transport. (3) $\alpha$ Helical peptides such as mastoparan and $\mathrm{Vpr}$ permeabilize mitochondrial membranes and induce PT. (4) Redox modulating compound such as diamide deplete GSH stores and oxidize and crosslink critical mitochondrial redox-sensitive thiol groups at the matrix surface of the PT. (5) mtDNA depleting agents such as ditercalinium inhibit respiration, electron transport and oxidative phosphorylation (see text for references). 
MKT-077, a cationic rhodacyanine dye, is selectively toxic to cancer cells in vitro and in vivo (Modica-Napolitano et al., 1996). The dye is being evaluated in phase I clinical trails due to a promising combination of anticancer effects and desirable pharmacological properties (Modica-Napolitano et al., 1996). A complete understanding of the drugs mechanism is not understood although more hydrophobic derivatives appear to perturb electron transport and oxidative phosphorylation whereas more hydrophilic derivatives target mitochondrial matrix proteins (Modica-Napolitano et al., 1996). The strategies described above for targeting the mitochondrial inner membrane and the mitochondrial permeability transition are shown schematically in Figure 2.

\section{Therapeutic strategies for targeting mitochondrial DNA}

A variety of chemical agents cause depletion of mitochondrial DNA (mtDNA) in mammalian cells and theoretically some of these could be used in cancer therapy. For example, 4-quinolone drugs such as ciprofloxacin cause a selective loss of mtDNA associated with loss of mitochondrial function (Lawrence et al., 1996). A number of lipophilic cations, including the intercalating anticancer drug, ditercalinium cause selective depletion of mtDNA from cultured mammalian cells by inhibiting DNA polymerase gamma activity and may be more selective in targeting mtDNA than ethidium bromide because of different distribution in mitochondria (Okamaoto et al., 2003). Other agents causing depletion of mtDNA in mammalian cells include antiviral nucleoside analogs (Anderson, 2001). Although the potential exists that some of these agents could be exploited for treating cancer, alterations in mtDNA are associated with a wide range of human diseases so that a greater understanding of the mtDNA metabolism is required prior to designing more effective and less toxic anticancer drugs that target mtDNA.

\section{Conclusions}

The differences in mitochondrial function between normal cells and cancer cells may offer a unique potential for the design of anticancer agents that deliver mitochondrial targeting drugs to selectively kill cancer cells. As discussed, one current chemotherapeutic strategy utilizes a selection of lipophilic cations that target cancer cell mitochondria due to their increased $\Delta \psi_{\mathrm{m}}$ and the possibility of linking these agents to a variety of thiol crosslinking agents to eradicate Bcl-2 overexpressing cells exists. Other chemotherapeutic strategies targeting Bcl-2 include using antisense oligonucleotides such as G3139 to downregulate Bcl-2 expression and promote apoptosis. Stable peptidomimetics including SAHBs have desirable pharmacological properties and can be employed to specifically target proapoptotic peptides to mitochondria to induce apoptosis. Other strategies include the use of specific peptides that are toxic by their disruption of mitochondrial membranes and $\Delta \psi_{\mathrm{m}}$, while a selection of drugs, including betulinic acid and LND target the PT. An alternative strategy may be to use the mitochondrial protein-import machinery to deliver toxic macromolecules to mitochondria while drugs targeting mtDNA such as ditercalinium may also offer unique opportunities for use in cancer therapy.

This review was supported by research grants from National of University Singapore (NUS) Academic Research Fund Grant R183000-127-112 and Biomedical Research Council (BMRC) of Singapore R183-000-132-305 to JSA.

\section{References}

ACKERMANN, E.J., TAYLOR, J.K., NARAYANA, R. \& BENNETT, C.F. (1999). The role of antiapoptotic Bcl-2 family members in endothelial apoptosis elucidated with antisense oligonucleotides. J. Biol. Chem., 274, 11245-11252.

ADACHI, M., HIGUCHI, H., MIURA, S., AZUMA, T., INOKUCHI, S., SAITO, H., KATO, S. \& ISHII, H. (2004). Bax interacts with the voltage-dependent anion channel and mediates ethanol-induced apoptosis in rat hepatocytes. Am. J. Physiol. Gastrointest. Liver Physiol., 287, G695-G705.

ANDERSON, K.S. (2001). The molecular basis of inhibition and toxicity of modified cytosine analogues targeting HIV-1 reverse transcriptase. Antivir. Chem. Chemother., 12 (Suppl 1), 13-17.

AQEILAN, R., YARKONI, S. \& LORBERBOUM-GALSKI, H. (1999). Interleukin 2-Bax: a novel prototype of human chimeric proteins for targeted therapy. FEBS Lett., 457, 271-276.

ARDAIL, D., PRIVAT, J.P., EGRET-CHARLIER, M., LEVRAT, C., LERME, F. \& LOUISOT, P. (1990). Mitochondrial contact sites. Lipid composition and dynamics. J. Biol. Chem., 265, $18797-18802$

ARMSTRONG, J.S. \& JONES, D.P. (2002). Glutathione depletion enforces the mitochondrial permeability transition and causes cell death in Bcl-2 overexpressing HL60 cells. FASEB J., 16, $1263-1265$.

ARMSTRONG, J.S., STEINAUER, K.K., HORNUNG, B., IRISH, J.M., LECANE, P., BIRRELL, G.W., PEEHL, D.M. \& KNOX, S.J. (2002). Role of glutathione depletion and reactive oxygen species generation in apoptotic signaling in a human B lymphoma cell line. Cell Death Differ., 9, 252-263.

ARMSTRONG, J.S., WHITEMAN, M., YANG, H., JONES, D.P. \& STERNBERG, JR P. (2004). Cysteine starvation activates the redox-dependent mitochondrial permeability transition in retinal pigment epithelial cells. Invest. Ophthalmol. Vis. Sci., 45, 4183-4189.

BAINES, C.P., KAISER, R.A., PURCELL, N.H., BLAIR, N.S., OSINSKA, H., HAMBLETON, M.A., BRUNSKILL, E.W., SAYEN, M.R., GOTTLIEB, R.A., DORN, G.W., ROBBINS, J. \& MOLKENTIN, J.D. (2005). Loss of cyclophilin D reveals a critical role for mitochondrial permeability transition in cell death. Nature, $\mathbf{4 3 4}$ 658-662.

BRECKENRIDGE, D.G. \& XUE, D. (2004). Regulation of mitochondrial membrane permeabilization by BCL-2 family proteins and caspases. Curr. Opin. Cell Biol., 16, 647-652.

BREDESEN, D.E. (2000). Apoptosis: overview and signal transduction pathways. J. Neurotrauma, 17, 801-810.

BRENNER, C., CADIOU, H., VIEIRA, H.L., ZAMZAMI, N., MARZO, I., XIE, Z., LEBER, B., ANDREWS, D., DUCLOHIER, H., REED, J.C. \& KROEMER, G. (2000). Bcl-2 and Bax regulate the channel activity of the mitochondrial adenine nucleotide translocator. Oncogene, 19, 329-336.

BRINI, M., MARSAUlt, R., BASTIANUTTO, C., ALVAREZ, J., POZZAN, T. \& RIZZUTO, R. (1995). Transfected aequorin in the measurement of cytosolic $\mathrm{Ca} 2+$ concentration $([\mathrm{Ca} 2+] \mathrm{c})$. A critical evaluation. J. Biol. Chem., 270, 9896-9903.

BRUSTOVETSKY, N. \& KLINGENBERG, M. (1996). Mitochondrial $\mathrm{ADP} / \mathrm{ATP}$ carrier can be reversibly converted into a large channel by $\mathrm{Ca} 2+$. Biochemistry, 35, 8483-8488. 
CAIN, K., BRATTON, S.B. \& COHEN, G.M. (2002). The Apaf-1 apoptosome: a large caspase-activating complex. Biochimie, 84, 203-214.

CHAI, J., DU, C., WU, J.W., KYIN, S., WANG, X. \& SHI, Y. (2000). Structural and biochemical basis of apoptotic activation by Smac/ DIABLO. Nature, 406, 855-862.

CHEN, L., WILLIS, S.N., WEI, A., SMITH, B.J., FLETCHER, J.I., HINDS, M.G., COLMAN, P.M., DAY, C.L., ADAMS, J.M. \& HUANG, D.C. (2005). Differential targeting of prosurvival Bcl-2 proteins by their $\mathrm{BH} 3$-only ligands allows complementary apoptotic function. Mol. Cell, 17, 393-403.

CHEN, L.B. (1988). Mitochondrial membrane potential in living cells. Annu. Rev. Cell Biol., 4, 155-181.

CHENG, E.H., SHEIKO, T.V., FISHER, J.K., CRAIGEN, W.J. \& KORSMEYER, S.J. (2003). VDAC2 inhibits BAK activation and mitochondrial apoptosis. Science, 301, 513-517.

CHERNYAK, B.V. \& BERNARDI, P. (1996). The mitochondrial permeability transition pore is modulated by oxidative agents through both pyridine nucleotides and glutathione at two separate sites. Eur. J. Biochem., 238, 623-630.

COSTANTINI, P., BELZACQ, A.S., VIEIRA, H.L., LAROCHETTE, N., DE PABLO, M.A., ZAMZAMI, N., SUSIN, S.A., BRENNER, C. \& KROEMER, G. (2000a). Oxidation of a critical thiol residue of the adenine nucleotide translocator enforces Bcl-2-independent permeability transition pore opening and apoptosis. Oncogene, 19, 307-314.

COSTANTINI, P., CHERNYAK, B.V., PETRONILLI, V. \& BERNARDI, P. (1996). Modulation of the mitochondrial permeability transition pore by pyridine nucleotides and dithiol oxidation at two separate sites. J. Biol. Chem., 271, 6746-6751.

COSTANTINI, P., JACOTOT, E., DECAUdin, D. \& KROEMER, G. (2000b). Mitochondrion as a novel target of anticancer chemotherapy. J. Natl. Cancer Inst., 92, 1042-1053.

CROMPTON, M. (1999). The mitochondrial permeability transition pore and its role in cell death. Biochem. J., 341, 233-249.

CROMPTON, M. (2000). Mitochondrial intermembrane junctional complexes and their role in cell death. J. Physiol., 529, $11-21$.

CROMPTON, M., VIRJI, S. \& WARD, J.M. (1998). Cyclophilin-D binds strongly to complexes of the voltage-dependent anion channel and the adenine nucleotide translocase to form the permeability transition pore. Eur. J. Biochem., 258, 729-735.

DANIEL, P.T., SCHULZE-OSTHOFF, K., BELKA, C. \& GUNER, D. (2003). Guardians of cell death: the Bcl-2 family proteins. Essays Biochem., 39, 73-88.

DE MARChI, U., CAMPEllo, S., SZABO, I., TOMBOLA, F., MARTINOU, J.C. \& ZORATTI, M. (2004). Bax does not directly participate in the $\mathrm{Ca}(2+)$-induced permeability transition of isolated mitochondria. J. Biol. Chem., 279, 37415-37422.

DEGLI ESPOSTI, M. \& DIVE, C. (2003). Mitochondrial membrane permeabilisation by Bax/Bak. Biochem. Biophys. Res. Commun., 304, 455-461.

EKERT, P.G. \& VAUX, D.L. (2005). The mitochondrial death squad: hardened killers or innocent bystanders? Curr. Opin. Cell Biol., 17, 626-630.

EPAND, R.F., MARTINOU, J.C., FORNALLAZ-MULHAUSER, M., HUGHES, D.W. \& EPAND, R.M. (2002). The apoptotic protein tBid promotes leakage by altering membrane curvature. J. Biol. Chem., 277, 32632-32639.

ESKES, R., DESAGHER, S., ANTONSSON, B. \& MARTINOU, J.C. (2000). Bid induces the oligomerization and insertion of Bax into the outer mitochondrial membrane. Mol. Cell. Biol., 20, 929-935.

FAGIAN, M.M., PEREIRA-DA-SILVA, L., MARTINS, I.S. \& VERCESI, A.E. (1990). Membrane protein thiol cross-linking associated with the permeabilization of the inner mitochondrial membrane by Ca2 + plus prooxidants. J. Biol. Chem., 265, 19955-19960.

FERNANDEZ-CHECA, J.C., GARCIA-RUIZ, C., COLELL, A., MORALES, A., MARI, M., MIRANDA, M. \& ARDITE, E. (1998). Oxidative stress: role of mitochondria and protection by glutathione. Biofactors, 8, 7-11.

FRUMAN, D.A., KLEE, C.B., BIERER, B.E. \& BURAKOFF, S.J. (1992). Calcineurin phosphatase activity in T lymphocytes is inhibited by FK 506 and cyclosporin A. Proc. Natl. Acad. Sci. U.S.A., 89, 3686-3690.
GADELHA, F.R., THOMSON, L., FAGIAN, M.M., COSTA, A.D., RADI, R. \& VERCESI, A.E. (1997). Ca2 +-independent permeabilization of the inner mitochondrial membrane by peroxynitrite is mediated by membrane protein thiol cross-linking and lipid peroxidation. Arch. Biochem. Biophys., 345, 243-250.

GAO, W., PU, Y., LUO, K.Q. \& CHANG, D.C. (2001). Temporal relationship between cytochrome $c$ release and mitochondrial swelling during UV-induced apoptosis in living HeLa cells. J. Cell Sci., 114, 2855-2862.

GORDON, D.M., DANCIS, A. \& PAIN, D. (2000). Mechanisms of mitochondrial protein import. Essays Biochem., 36, 61-73.

GOTTLIEB, R.A. (2000). Mitochondria: execution central. FEBS Lett. 482, 6-12.

GREEN, D.R. \& KROEMER, G. (2004). The pathophysiology of mitochondrial cell death. Science, 305, 626-629.

GREEN, D.R. \& REED, J.C. (1998). Mitochondria and apoptosis. Science, 281, 1309-1312.

GRIFFITH, O.W. \& MEISTER, A. (1985). Origin and turnover of mitochondrial glutathione. Proc. Natl. Acad. Sci. U.S.A., 82, $4668-4672$.

GUO, B., ZHAI, D., CABEZAS, E., WELSH, K., NOURAINI, S., SATTERTHWAIT, A.C. \& REED, J.C. (2003). Humanin peptide suppresses apoptosis by interfering with Bax activation. Nature, 423, 456-461.

HALESTRAP, A.P., CLARKE, S.J. \& JAVADOV, S.A. (2004). Mitochondrial permeability transition pore opening during myocardial reperfusion - a target for cardioprotection. Cardiovasc. Res., 61, 372-385.

HALESTRAP, A.P., MCSTAY, G.P. \& CLARKE, S.J. (2002). The permeability transition pore complex: another view. Biochimie, $\mathbf{8 4}$ $153-166$.

HAWORTH, R.A. \& HUNTER, D.R. (1979). The Ca2+-induced membrane transition in mitochondria. II. Nature of the $\mathrm{Ca} 2+$ trigger site. Arch. Biochem. Biophys., 195, 460-467.

HIRSCH, T., DECAUDIN, D., SUSIN, S.A., MARCHETTI, P., LAROCHETTE, N., RESCHE-RIGON, M. \& KROEMER, G. (1998). PK11195, a ligand of the mitochondrial benzodiazepine receptor, facilitates the induction of apoptosis and reverses Bcl-2-mediated cytoprotection. Exp. Cell Res., 241, 426-434.

HOCKENBERY, D.M., OLTVAI, Z.N., YIN, X.M., MILLIMAN, C.L. \& KORSMEYER, S.J. (1993). Bcl-2 functions in an antioxidant pathway to prevent apoptosis. Cell, 75, 241-251.

IRVINE, R.A., ADACHI, N., SHIBATA, D.K., CASSELL, G.D., YU, K. KARANJAWALA, Z.E., HSIEH, C.L. \& LIEBER, M.R. (2005). Generation and characterization of endonuclease $G$ null mice. Mol. Cell. Biol., 25, 294-302.

ITO, T., DENG, X., CARR, B. \& MAY, W.S. (1997). Bcl-2 phosphorylation required for anti-apoptosis function. J. Biol. Chem., 272, $11671-11673$.

JACOTOT, E., RAVAGNAN, L., LOEFFLER, M., FERRI, K.F., VIEIRA, H.L., ZAMZAMI, N., COSTANTINI, P, DRUILLENNEC, S., HOEBEKE, J., BRIAND, J.P., IRINOPOULOU, T., DAUGAS, E., SUSIN, S.A., COINTE, D., XIE, Z.H., REED, J.C., ROQUES, B.P. \& KROEMER, G. (2000). The HIV-1 viral protein R induces apoptosis via a direct effect on the mitochondrial permeability transition pore. J. Exp. Med., 191, 33-46.

JIN, S., KALKUM, M., OVERHOLTZER, M., STOFFEL, A., CHAIT, B.T. \& LEVINE, A.J. (2003). CIAP1 and the serine protease HTRA2 are involved in a novel p53-dependent apoptosis pathway in mammals. Genes Dev., 17, 359-367.

JONES, J.M., DATTA, P., SRINIVASULA, S.M., JI, W., GUPTA, S. ZHANG, Z., DAVIES, E., HAJNOCZKY, G., SAUNDERS, T.L., VAN KEUREN, M.L., FERNANDES-ALNEMRI, T., MEISLER, M.H. \& ALNEMRI, E.S. (2003). Loss of OMI mitochondrial protease activity causes the neuromuscular disorder of mnd 2 mutant mice. Nature, 425, 721-727.

KAGAWA, S., PEARSON, S.A., JI, L., XU, K., MCDONNELL, T.J., SWISHER, S.G., ROTH, J.A. \& FANG, B. (2000). A binary adenoviral vector system for expressing high levels of the proapoptotic gene bax. Gene Therapy, 7, 75-79. [Medline].

KIM, J.S., HE, L., QIAN, T. \& LEMASTERS, J.J. (2003). Role of the mitochondrial permeability transition in apoptotic and necrotic death after ischemia/reperfusion injury to hepatocytes. Curr. Mol. Med., 3, 527-535. 
KORSMEYER, S.J., WEI, M.C., SAITO, M., WEILER, S., OH, K.J. \& SCHLESINGER, P.H. (2000). Pro-apoptotic cascade activates BID, which oligomerizes BAK or BAX into pores that result in the release of cytochrome c. Cell Death Differ., 7, 1166-1173.

KOWALTOWSKI, A.J., CASTILHO, R.F. \& VERCESI, A.E. (2001). Mitochondrial permeability transition and oxidative stress. FEBS Lett., 495, 12-15.

KROEMER, G. (2002). Introduction: mitochondrial control of apoptosis. Biochimie, 84, 103-104.

KUWANA, T. \& NEWMEYER, D.D. (2003). Bcl-2-family proteins and the role of mitochondria in apoptosis. Curr. Opin. Cell Biol., 15, 691-699.

LAROCHETTE, N., DECAUDIN, D., JACOTOT, E., BRENNER, C., MARZO, I., SUSIN, S.A., ZAMZAMI, N., XIE, Z., REED, J. \& KROEMER, G. (1999). Arsenite induces apoptosis via a direct effect on the mitochondrial permeability transition pore. Exp. Cell Res., 249, 413-421 [Medline].

LAWRENCE, J.W., CLAIRE, D.C., WEISSIG, V. \& ROWE, T.C. (1996). Delayed cytotoxicity and cleavage of mitochondrial DNA in ciprofloxacin-treated mammalian cells. Mol. Pharmacol., 50, $1178-1188$.

LEMASTERS, J.J., NIEMINEN, A.L., QIAN, T., TROST, L.C., ELMORE, S.P., NISHIMURA, Y., CROWE, R.A., CASCIO, W.E., BRADHAM, C.A., BRENNER, D.A. \& HERMAN, B. (1998). The mitochondrial permeability transition in cell death: a common mechanism in necrosis, apoptosis and autophagy. Biochim. Biophys. Acta, 1366, 177-196.

LI, L., THOMAS, R.M., SUZUKI, H., DE BRABANDER, J.K., WANG, X. \& HARRAN, P.G. (2004). A small molecule Smac mimic potentiates TRAIL- and TNFalpha-mediated cell death. Science, 305, 1471-1474.

LI, X., MARANI, M., YU, J., NAN, B., ROTH, J.A., KAGAWA, S., FANG, B., DENNER, L. \& MARCELLI, M. (2001). Adenovirusmediated Bax overexpression for the induction of therapeutic apoptosis in prostate cancer. Cancer Res., 61, 186-191.

MARCHETTI, P., CASTEDO, M., SUSIN, S.A., ZAMZAMI, N., HIRSCH, T., MACHO, A., HAEFFNER, A., HIRSCH, F., GEUSKENS, M. \& KROEMER, G. (1996). Mitochondrial permeability transition is a central coordinating event of apoptosis. J. Exp. Med., 184, $1155-1160$

MARCHETTI, P., ZAMZAMI, N., JOSEPH, B., SCHRAEN-MASCHKE, S., MEREAU-RICHARD, C., COSTANTINI, P., METIVIER, D., SUSIN, S.A., KROEMER, G. \& FORMSTECHER, P. (1999). The novel retinoid 6-[3-(1-adamantyl)-4-hydroxyphenyl]-2-naphtalene carboxylic acid can trigger apoptosis through a mitochondrial pathway independent of the nucleus. Cancer Res., 54, 6257-6266.

MARCUCCI, G., STOCK, W., DAI, G., KLISOVIC, R.B., LIU, S., KLISOVIC, M.I., BLUM, W., KEFAUVER, C., SHER, D.A., GREEN, M., MORAN, M., MAHARRY, K., NOVICK, S., BLOOMFIELD, C.D., ZWIEBEL, J.A., LARSON, R.A., GREVER, M.R., CHAN, K.K. \& BYRD, J.C. (2005). Phase I study of oblimersen sodium, an antisense to Bcl-2, in untreated older patients with acute myeloid leukemia: pharmacokinetics, pharmacodynamics, and clinical activity. J. Clin. Oncol., 23, 3404-3411.

MARTENSSON, J., LAI, J.C. \& MEISTER, A. (1990). High-affinity transport of glutathione is part of a multicomponent system essential for mitochondrial function. Proc. Natl. Acad. Sci. U.S.A., 87, 7185-7189.

MARTINOU, I., DESAGHER, S., ESKES, R., ANTONSSON, B., ANDRE, E., FAKAN, S. \& MARTINOU, J.C. (1999). The release of cytochrome $c$ from mitochondria during apoptosis of NGFdeprived sympathetic neurons is a reversible event. J. Cell Biol., 144, 883-889.

MARTINS, L.M., MORRISON, A., KLUPSCH, K., FEDELE, V., MOISOI, N., TEISMANN, P., ABUIN, A., GRAU, E., GEPPERT, M., LIVI, G.P., CREASY, C.L., MARTIN, A., HARGREAVES, I., HEALES, S.J., OKADA, H., BRANDNER, S., SCHULZ, J.B., MAK, T. \& DOWNWARD, J. (2004). Neuroprotective role of the Reaperrelated serine protease $\mathrm{HtrA} / \mathrm{Omi}$ revealed by targeted deletion in mice. Mol. Cell. Biol., 24, 9848-9862.

MARZO, I., BRENNER, C., ZAMZAMI, N., JURGENSMEIER, J.M., SUSIN, S.A., VIEIRA, H.L., PREVOST, M.C., XIE, Z., MATSUYAMA, S., REED, J.C. \& KROEMER, G. (1998). Bax and adenine nucleotide translocator cooperate in the mitochondrial control of apoptosis. Science, 281, 2027-2031.
MATE, M.J., ORTIZ-LOMBARdiA, M., BOITEl, B., HAOUZ, A., TELLO, D., SUSIN, S.A., PENNINGER, J., KROEMER, G. \& ALZARI, P.M. (2002). The crystal structure of the mouse apoptosis-inducing factor AIF. Nat. Struct. Biol., 9, 442-446.

MCENERY, M.W., SNOWMAN, A.M., TRIFILETTI, R.R. \& SNYDER, S.H. (1992). Isolation of the mitochondrial benzodiazepine receptor: association with the voltage-dependent anion channel and the adenine nucleotide carrier. Proc. Natl. Acad. Sci. U.S.A., 89, 3170-3174.

MIRAMAR, M.D., COSTANTINI, P., RAVAGNAN, L., SARAIVA, L.M., HAOUZI, D., BROTHERS, G., PENNINGER, J.M., PELEATO, M.L., KROEMER, G. \& SUSIN, S.A. (2001). NADH oxidase activity of mitochondrial apoptosis-inducing factor. J. Biol. Chem., 276, 16391-16398.

MIYASHITA, T. \& REED, J.C. (1992). Bcl-2 gene transfer increases relative resistance of S49.1 and WEHI7.2 lymphoid cells to cell death and DNA fragmentation induced by glucocorticoids and multiple chemotherapeutic drugs. Cancer Res., 52, 5407-5411.

MODICA-NAPOLITANO, J.S., KOYA, K., WEISBERG, E., BRUNELLI, B.T., LI, Y. \& CHEN, L.B. (1996). Selective damage to carcinoma mitochondria by the rhodacyanine MKT-077. Cancer Res., 56, 544-550.

MURPHY, M.P. (1997). Selective targeting of bioactive compounds to mitochondria. Trends Biotechnol., 15, 326-330.

NAKAGAWA, T., SHIMIZU, S., WATANABE, T., YAMAGUCHI, O., OTSU, K., YAMAGATA, H., INOHARA, H., KUBO, T. \& TSUJIMOTO, Y. (2005). Cyclophilin D-dependent mitochondrial permeability transition regulates some necrotic but not apoptotic cell death. Nature, 434, 652-658.

NECHUSHTAN, A., SMITH, C.L., HSU, Y.T. \& YOULE, R.J. (1999) Conformation of the Bax C-terminus regulates subcellular location and cell death. EMBO J., 18, 2330-2341.

NOMURA, M., SHIMIZU, S., SUGIYAMA, T., NARITA, M., ITO, T., MATSUDA, H. \& TSUJIMOTO, Y. (2003). 14-3-3 Interacts directly with and negatively regulates pro-apoptotic Bax. J. Biol. Chem., 278, 2058-2065.

OKAMAOTO, M., OHSATO, T., NAKADA, K., ISOBE, K., SPELBRINK, J.N., HAYASHI, J., HAMASAKI, N. \& KANG, D. (2003). Ditercalinium chloride, a pro-anticancer drug, intimately associates with mammalian mitochondrial DNA and inhibits its replication. Curr. Genet., 43, 364-370.

PETRONILLI, V., COSTANTINI, P., SCORRANO, L., COLONNA, R., PASSAMONTI, S. \& BERNARDI, P. (1994). The voltage sensor of the mitochondrial permeability transition pore is tuned by the oxidation-reduction state of vicinal thiols. Increase of the gating potential by oxidants and its reversal by reducing agents. J. Biol. Chem., 269, 16638-16642.

PETROSIllo, G., RUGGIERO, F.M. \& PARADIES, G. (2003). Role of reactive oxygen species and cardiolipin in the release of cytochrome $c$ from mitochondria. FASEB J., 17, 2202-2208.

PFEIFFER, D.R., GUDZ, T.I., NOVGORODOV, S.A. \& ERDAHL, W.L. (1995). The peptide mastoparan is a potent facilitator of the mitochondrial permeability transition. J. Biol. Chem., 270, 4923-4932.

RAVAGNAN, L., MARZO, I., COSTANTINI, P., SUSIN, S.A., ZAMZAMI, N., PETIT, P.X., HIRSCH, F., GOULBERN, M., POUPON, M.F., MICCOLI, L., XIE, Z., REED, J.C. \& KROEMER, G. (1999) Lonidamine triggers apoptosis via a direct, Bcl-2-inhibited effect on the mitochondrial permeability transition pore. Oncogene, $\mathbf{1 8}$ $2537-2546$.

SAWADA, M., SUN, W., HAYES, P., LESKOV, K., BOOTHMAN, D.A. \& MATSUYAMA, S. (2003). Ku70 suppresses the apoptotic translocation of Bax to mitochondria. Nat. Cell Biol., 5, 320-329.

SCHEFFLER, I.E. (2001). Mitochondria make a come back. Adv. Drug Deliv. Rev., 49, 3-26.

SCHINDER, A.F., OLSON, E.C., SPITZER, N.C. \& MONTAL, M. (1996) Mitochondrial dysfunction is a primary event in glutamate neurotoxicity. J. Neurosci., 16, 6125-6133.

SCHINZEL, A., KAUFMANN, T., SCHULER, M., MARTINALBO, J., GRUBB, D. \& BORNER, C. (2004). Conformational control of Bax localization and apoptotic activity by Pro168. J. Cell Biol., 164, 1021-1032. [Epub 2004 Mar 22].

SCHULER, W., WECKER, K., DE ROCQUIGNY, H., BAUDAT, Y., SIRE, J. \& ROQUES, B.P. (1999). NMR structure of the (52-96) C-terminal domain of the HIV-1 regulatory protein Vpr: molecular insights into its biological functions. J. Mol. Biol., 285, 2105-2117. 
SCHULTZ, D.R. \& HARRINGTON JR, W.J. (2003). Apoptosis: programmed cell death at a molecular level. Semin. Arthritis Rheum., 32, 345-369.

SEDLAK, T.W., OLTVAI, Z.N., YANG, E., WANG, K., BOISE, L.H., THOMPSON, C.B. \& KORSMEYER, S.J. (1995). Multiple Bcl-2 family members demonstrate selective dimerizations with Bax. Proc. Natl. Acad. Sci. U.S.A., 92, 7834-7838.

SHI, Y. (2002). Mechanisms of caspase activation and inhibition during apoptosis. Mol. Cell, 9, 459-470.

SMAILI, S.S., HSU, Y.T., YOULE, R.J. \& RUSSELL, J.T. (2000). Mitochondria in $\mathrm{Ca} 2+$ signaling and apoptosis. J. Bioenerg. Biomembr., 32, 35-46.

STEINMAN, H.M. (1995). The Bcl-2 oncoprotein functions as a pro-oxidant. J. Biol. Chem., 270, 3487-3490.

STRYKER, J.A. \& GERWECK, L.E. (1988). Lonidamine-induced, pH dependent inhibition of cellular oxygen utilization. Radiat. Res., 113, 356-361.

SUSIN, S.A., LORENZO, H.K., ZAMZAMI, N., MARZO, I., SNOW, B.E., BROTHERS, G.M., MANGION, J., JACOTOT, E., COSTANTINI, P., LOEFFLER, M., LAROCHETTE, N., GOODLETT, D.R., AEBERSOLD, R., SIDEROVSKI, D.P., PENNINGER, J.M. \& KROEMER, G. (1999). Molecular characterization of mitochondrial apoptosis-inducing factor. Nature, 397, 441-446.

SUSIN, S.A., ZAMZAMI, N., CASTEDO, M., HIRSCH, T., MARCHETTI, P., MACHO, A., DAUGAS, E., GEUSKENS, M. \& KROEMER, G. (1996). Bcl-2 inhibits the mitochondrial release of an apoptogenic protease. J. Exp. Med., 184, 1331-1341.

SUZUKI, Y., IMAI, Y., NAKAYAMA, H., TAKAHASHI, K., TAKIO, K. \& TAKAHASHI, R. (2001). A serine protease, HtrA2, is released from the mitochondria and interacts with XIAP, inducing cell death. Mol. Cell, 8, 613-621.

VAHSEN, N., CANDE, C., BRIERE, J.J., BENIT, P., JOZA, N., LAROCHETTE, N., MASTROBERARDINO, P.G., PEQUIGNOT, M.O., CASARES, N., LAZAR, V., FERAUD, O., DEBILI, N., WISSING, S., ENGELHARDT, S., MADEO, F., PIACENTINI, M., PENNINGER, J.M., SCHAGGER, H., RUSTIN, P. \& KROEMER, G. (2004). AIF deficiency compromises oxidative phosphorylation. EMBO J., 23, 4679-4689.

VAN LOO, G., SAELENS, X., VAN GURP, M., MACFARLANE, M., MARTIN, S.J. \& VANDENABEELE, P. (2002). The role of mitochondrial factors in apoptosis: a Russian roulette with more than one bullet. Cell Death Differ., 9, 1031-1042.

VANDER HEIDEN, M.G., CHANDEL, N.S., WILLIAMSON, E.K., SCHUMACKER, P.T. \& THOMPSON, C.B. (1997). Bcl-xL regulates the membrane potential and volume homeostasis of mitochondria. Cell, 91, 627-637.

VON AHSEN, O., RENKEN, C., PERKINS, G., KLUCK, R.M., BOSSY-WETZEL, E. \& NEWMEYER, D.D. (2000). Preservation of mitochondrial structure and function after Bid- or Bax-mediated cytochrome $c$ release. J. Cell Biol., 150, 1027-1036.
WAJANT, H. (2002). The Fas signaling pathway: more than a paradigm. Science, 296, 1635-1636.

WALDMEIER, P.C., ZIMMERMANN, K., QIAN, T., TINTELNOTBLOMLEY, M. \& LEMASTERS, J.J. (2003). Cyclophilin D as a drug target. Curr. Med. Chem., 10, 1485-1506.

WALENSKY, L.D., KUNG, A.L., ESCHER, I., MALIA, T.J., BARBUTO, S., WRIGHT, R.D., WAGNER, G., VERDINE, G.L. \& KORSMEYER, S.J. (2004). Activation of apoptosis in vivo by a hydrocarbon-stapled BH3 helix. Science, 305, 1466-1470.

WARING, P. \& BEAVER, J. (1996). Cyclosporin A rescues thymocytes from apoptosis induced by very low concentrations of thapsigargin: effects on mitochondrial function. Exp. Cell Res., 227, 264-276.

WIDLAK, P. \& GARRARD, W.T. (2005). Discovery, regulation, and action of the major apoptotic nucleases DFF40/CAD and endonuclease G. J. Cell Biochem., 94, 1078-1087.

WOODFIELD, K., RUCK, A., BRDICZKA, D. \& HALESTRAP, A.P. (1998). Direct demonstration of a specific interaction between cyclophilin-D and the adenine nucleotide translocase confirms their role in the mitochondrial permeability transition. Biochem. J., 336, 287-290.

WU, G., CHAI, J., SUBER, T.L., WU, J.W., DU, C., WANG, X. \& SHI, Y (2000). Structural basis of IAP recognition by Smac/DIABLO. Nature, 408, 1008-1012.

XIANG, J., GOMEZ-NAVARRO, J., ARAFAT, W., LIU, B., BARKER, S.D., AlvareZ, R.D., SIEGAL, G.P. \& CURIEL, D.T. (2000). Pro-apoptotic treatment with an adenovirus encoding Bax enhances the effect of chemotherapy in ovarian cancer. J. Gene Med., 2, 97-106.

YIN, X.M., OLTVAI, Z.N. \& KORSMEYER, S.J. (1994). BH1 and BH2 domains of $\mathrm{Bcl}-2$ are required for inhibition of apoptosis and heterodimerization with Bax. Nature, 369, 321-323.

ZAMZAMI, N., MARZO, I., SUSIN, S.A., BRENNER, C., LAROCHETTE, N., MARCHETTI, P., REED, J., KOFLER, R. \& KROEMER, G. (1998). The thiol crosslinking agent diamide overcomes the apoptosis-inhibitory effect of $\mathrm{Bcl}-2$ by enforcing mitochondrial permeability transition. Oncogene, 16, 1055-1063.

ZHU, X.H., SHEN, Y.L., JING, Y.K., CAI, X., JIA, P.M., HUANG, Y., TANG, W., SHI, G.Y., SUN, Y.P., DAI, J., WANG, Z.Y., CHEN, S.J., ZHANG, T.D., WAXMAN, S., CHEN, Z. \& CHEN, G.Q. (1999). Apoptosis and growth inhibition in malignant lymphocytes after treatment with arsenic trioxide at clinically achievable concentrations. J. Natl. Cancer Inst., 91, 772-778.

ZORATTI, M. \& SZABO, I. (1995). The mitochondrial permeability transition. Biochim. Biophys. Acta, 124, 139-176.

(Received August 22, 2005

Revised October 21, 2005

Accepted October 23, 2005

Published online 5 December 2005 